
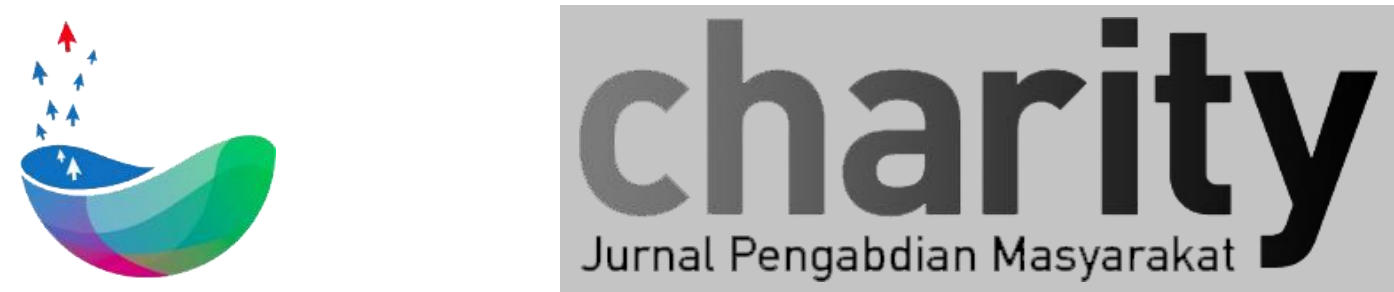

\title{
Pengolahan Kopi Tepat Guna Mendukung Pertanian Berkelanjutan Di Desa Telagah, Sei Bingei, Langkat
}

\author{
Ameilia Zuliyanti Siregar ${ }^{1 *}$, Yunilas ${ }^{2}, \operatorname{Irsal}^{1}$ \\ ${ }^{1}$ Program Studi Agroteknologi, Fakultas Pertanian, Universitas Sumatera Utara \\ ${ }^{2}$ Departemen Peternakan, Fakultas Pertanian Universitas Sumatera Utara \\ * ameiliazuliyanti@gmail.com
}

\section{INFO ARTIKEL}

Diterima 18 Desember 2021

Direvisi 13 Januari 2022

Disetujui 19 Januari 2022

Tersedia Online 24 Januari 2022
Keyword: Kopi, Arabika, minuman, Telagah, Sumatera.

\begin{abstract}
ABSTRAK
Negara yang termasuk pengekspor kopi terbesar di dunia adalah Brazil, Vietnam, Kolombia dan Indonesia. Kopi spesialti Indonesia yang memiliki nilai ekonomi tinggi salah satunya adalah Kopi Arabica Aceh Tengah (Ateng). Kualitas kopi dipengaruhi oleh varietas kopi, pengendalian hama terpadu kopi, lokasi budidaya kopi, pemanenan kopi serta pengolahan pasca panen kopi. Petani kopi di daerah mitra di Desa Telagah, Kecamatan Sei Bingei, Kabupaten Langkat teridentifikasi memiliki pengetahuan rendah, keterampilan sederhana, modal terbatas dalam budidaya dan pengelolaan kopi masih tradisional. Oleh sebab itu, sangat penting dilakukan kegiatan Pengabdian Desa Binaan (PDB) LPPM USU bekerjasama dengan Fakultas Kedokteran USU untuk menganalisis permasalahan dan strategi pengembangan dan konservasi kopi, minuman penikmat rasa yang trendi masa kini. Kelompok petani kopi 'Telagah', satu alternatif pemecahan masalah dengan 'pengolahan kopi tepat guna', edukasi budidaya dan pengelolaan kopi diharapkan dapat mendukung ekonomi kreatif berkonsepkan ekosistem berkelanjutan, mengenalkan kepada masyarakat budidaya kopi sebagai wahana edukasi dan produksi yang meningkatkan kesejahteraan petani kopi. Kegiatan pengabdian meliputi pelatihan, bimbingan teknis, dan pendampingan yang akan diintroduksi kepada mitra dalam bentuk induksi dan adopsi pengetahuan tentang pengendalian hama terpadu kopi secara kimiawi, pengelolaan limbah kopi dan mekanisme pengupasan kulit kopi mekanik. Teknologi yang akan diterapkan adalah pemanfaatan mikroorganisme untuk mengelola biji kopi menjadi pakan ternak serta memberi bantuan alat pengupas biji kopi (pulper pulp) kepada mitra. Program PDB Kopi Telagah diharapkan bersinergi antara akademisi, masyarakat, pemerintah dan stakeholder untuk mencapai tujuan mewujudkan Desa Telagah sebagai model harmoni masyarakat akan meningkatkan kualitas, keseragaman dan kuantitas kopi yang dapat membantu meningkatkan produktivitas dan profit petani kopi di Desa Telagah, Sei Bingei, Sumatera Utara.
\end{abstract}

ORCID ID: https://doi.org/0000-0002-7077-9852/

Paper_reg_number xxx (C) The Authors. Published by Directorate of Research and Community Service, Telkom University.

This is an open access article under the xxx license (https://creativecommons.org/licenses/xxx) 


\section{Pendahuluan}

\subsection{Analisis Situasi}

Komoditas tropis utama yang diperdagangkan di seluruh dunia dengan kontribusi setengah dari total ekspor komoditas tropis adalah kopi. Popularitas dan daya tarik dunia terhadap kopi, dikarenakan oleh rasanya yang unik serta didukung oleh faktor sejarah, tradisi, sosial dan kepentingan ekonomi [1]. Selain itu, kopi adalah salah satu sumber alami kafein [2] merupakan zat yang dapat menyebabkan peningkatan kewaspadaan dan mengurangi kelelahan [3]. Minuman kopi, minuman dengan bahan dasar ekstrak biji kopi, dikonsumsi sekitar 2,25 milyar gelas setiap hari diseluruh dunia [4]. Pada tahun 2013, International Coffee Organization (ICO) memperkirakan bahwa kebutuhan bubuk kopi dunia sekitar 8,77 juta ton [5].

Tanaman kopi (Coffea arabica) termasuk kelompok tanaman semak belukar dengan genus Coffea. Linnaeus merupakan orang pertama yang mendeskripsikan spesies kopi arabika (C. arabica) pada tahun 1753 [6]. Kini lebih dari 120 spesies kopi telah diidentifikasi namun hanya satu spesies yaitu Coffea canephora atau kopi robusta yang dibudidayakan mendekati kuantitas kopi arabika di seluruh dunia [7]. Kopi arabika mandheling merupakan kopi yang pertama kali diperkenalkan oleh Belanda pada tahun 1833 dan pertama kali ditanam di kawasan Mandailing Natal (Madina). Kopi varietas ini pernah dinobatkan sebagai kopi terbaik di dunia dan memiliki harga tertinggi di pasar internasional.

Desa Telagah, Langkat merupakan salah satu desa wisata yang memiliki sumber daya alam dan sumber pertanian dan kehutanan yang beranekaragaman. Langkat terdiri dari 23 kecamatan, 37 kelurahan, dan 240 desa dengan luas wilayah mencapai $6.262,00 \mathrm{~km}^{2}$ dan jumlah penduduk sekitar 1.032.330 jiwa (2017) dengan kepadatan penduduk 165 jiwa $/ \mathrm{km}^{2}$ [10].

Wisata dimulai dari air terjun jodoh yang fenomenal di tengah hutan liar begitu eksotik, memukau, dan menantang. Di beberapa dusun sudah ada dikelola objek wisata yang luar biasa. Dusun Pamah Simelir, Pamah, Perteguhen, Lau Tembo, Telagah D, Ujung Langkat, Sukaribu, Lau Buluh, dan lainnya. Di Dusun Pamah Simelir misalnya, pengunjung disajikan pesona alam Penatapen Kempu Pengulu Pamah Simelir dan Penatapen Kempu Tigan, Kolam Renang KKBS, Sabah Simelir, Camping Ground Karona Sakti. Di lokasi ini pengunjung akan dimanjakan dengan hembusan angin dan pemandangan bak serasa di luar negeri. Selanjutnya, di Dusun Perteguhen ada Puncak Adem, Puncak Akui, Habitat, dan Kolam Renang Mata Air Thevary di Bekulap yang kejernihan airnya sungguh luar biasa. Air yang mengalir dari tengah belantara TNGL selain belum tercemar karena bersih sehingga menurut warga setempat langsung diminum pun membuat badan terasa segar. Di Dusun Lau Tembo ada Puncak One Heart Batu Mbelang. Di Dusun Ujung Langkat ada Bekancan River. Dan banyak lagi potensi wisata yang masih dapat digali dan dikembangkan, disamping potensi bidang pertanian dan perkebunan.

Di Desa Telagah diidentifikasi sumber pencaharian bidang pertanian, yaitu: padi, tanaman sayuran, buah-buahan, asam gelugor, tanaman 
perkebunan seperti bamboo, kecombrang, dan lainnya. Sebelum tahun 2000 an, semua kopi arabika yang berasal dari Sumatera dikenal dengan kopi Mandaheling, baik dari Aceh Tengah (kopi Gayo), Sidikalang, Simalungun. Diprediksikan tanaman kopi cocok tumbuh pada ketinggian tempat di atas 500-700 $\mathrm{m}$ di atas permukaan laut (dpl), $1500-2500 \mathrm{~mm}$ per tahun, dengan rata-rata bulan kering 1-3 bulan dan suhu rata-rata 15-25 derajat celcius dengan lahan kelas S1 atau S2 $(12,13)$ di Desa Telagah, Langkat.

Tanaman kopi dapat diperbanyak dengan cara vegetatif menggunakan bagian dari tanaman dan generatif menggunakan benih atau biji. Perbanyakan secara generatif lebih umum digunakan karena mudah dalam pelaksanaanya, lebih singkat untuk menghasilkan bibit siap tanam dibandingkan dengan perbanyakan bibit secara vegetatif (klonal). Beberapa kelebihan yang dimiliki perbanyakan kopi secara klonal adalah sebagai berikut: mempunyai sifat yang sama dengan tanaman tetuanya, mutu hasil seragam, memanfaatkan dua sifat unggul batang atas dan batang bawah, memiliki umur mulai berbuah (prekositas) lebih awal, sambungan dan setek merupakan perbanyakan tanaman kopi secara klonal yang umum dilakukan para petani kopi. Namun proses pemangkasan dan PHT masih terbatas dilakukan petani kop karena kurangnya pengetahuan dan keterampilan petani dalam mengelola kopi (Gambar 1).

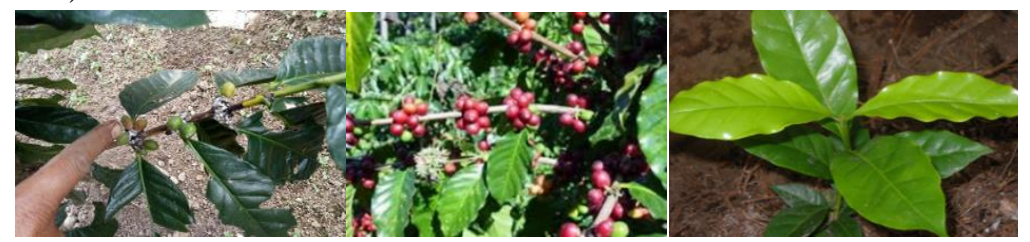

(a)

(b)

(c)

Gambar 1a. Deteksi Serangan HPT kopi ; b. Buah; c. Daun kopi di DesaTelagah, Langkat

Mitra petani kopi di Telagah umumnya melakukan kegiatan pascapanen kopi secara manual, salah satunya pada tahapan pengupasan kulit buah kopi yaitu dengan menggunakan alu, dimana buah kopi yang dikupas menggunakan alu bisa rusak karena tertekan sehingga meningkatkan losses kopi. Selain itu, dibutuhkan tenaga khusus untuk melakukan kegiatan ini sehingga kurang efisien.

Pengupasan kulit buah kopi dapat dilakukan menggunakan mesin yang biasa disebut mesin pulper kopi. Namun, harga dari alsintan ini dan akses untuk membelinya menjadi kendala petani kopi mandheling di daerah mitra. Keterbatasan pengetahuan petani kopi di Desa Muara Saladi dalam pemanfaatan alsintan dalam kegiatan pengolahan pasca panen kopi menjadi dasar dilakukannya kegiatan pengabdian kepada masyarakat di daerah tersebut.

\subsection{Identifikasi Permasalahan Mitra Kopi}

- Potensi luas lahan di Desa Telagah dapat dikembangkan untuk luas areal agroforestry kopi.

- Identifikasi mekanisme pengolahan limbah tanaman kopi. 
- Keterbatasan pengetahuan mitra dalam proses pascapanen kopi menggunakan alat dan mesin pertanian

\subsection{Manfaat Pengabdian Desa Binaan (PDB)}

- Memanfaatkan lahan untuk bidang pertanian dalam menumbuhkembangkan areal pertanaman kopi tepat guna di Desa Telagah, Langkat.

- Memberi pengetahuan tentang pengolahan limbah tanaman kopi menjadi pakan ternak.

- Memberikan pengetahuan dan keterampilan pengolahan kopi secara tepat guna.

\section{SOLUSI PERMASALAHAN}

Selanjutnya petani kopi diharapkan dapat menyediakan benih kopi unggul untuk menghasilkan produksi kopi yang tinggi. Bibit kopi tersebut harus sudah cukup umur dan ukurannya sudah memenuhi syarat standard. Panen pertama minimal 3 tahun setelah penanaman, tidak mudah terserang penyakit, hasil panennya banyak dan stabil sepanjang tahun, dapat berbuah dengan cepat, bentuk dan ukurannya biji kopi seragam, buahnya memiliki rasa dan aroma khas kopi, ukuran buahnya besar dengan biji yang besar pula, serta anting tanaman kopi juga terisi buah kopi, kulit buah tipis dengan ketebalan daging, kadar air daging sedikit dan ukuran buah besar, mempunyai ketahanan yang tinggi terhadap hama, penyakit, dan cendawan, serta struktur pohon kokoh dan percabangan merata [12,13,14].

Ketersediaan bibit kopi arabika menjadi kendala karena diperoleh dari lokasi yang cukup jauh dari Aceh Tengah. Pusat Penelitian Kopi dan Kakao (Puslitkoka) mengidentifikasi penelitian dan pengembangan komoditas kopi dan kakao secara nasional. Bibit kopi berkualitas yang sesuai dengan permintaan pembudidaya sangat terbatas [15]. Permintaan biji kopi yang semakain tinggi dan digemari oleh masyarakat dari kalangan muda, tua, anakanak dan dewasa di seluruh Indonesia menjadi alasan utama petani kopi untuk meningkatkan produksi kopi memenuhi kebutuhan masyarakat Sumatera Utara.

Solusi terhadap permasalahan masyarakat/mitra Desa Telagah, Kec. Sei Bingei, Langkat dibahas dalam analisa SWOT (Strenghts, Weakness, Oppurtunities and Threats) yang disajikan dalam Gambar 2 dibawah ini. Kegiatan yang kami tawarkan dimulai dari inventarisasi varietas kopi arabika, penyuluhan, pengelolaan dan pengendalian hama terpadu (PHT), pelatihan teredukasi seperti: pengaturan pola tanam kopi arabika, pembuatan pupuk poduktif, pembuatan pestisida nabati ramah lingkungan dan pendampingan petani.

Disamping itu perlu dilakukan inventarisasi dan pemetaaan keberadaan lokasi penanaman kopi arabika di Desa Telagah. Bantuan dan peningkatan bibit kopi berkualitas perlu ditumbuhkembangkan untuk peningkatan produksi dan komoditas minuman pemikat ini. Pelatihan pembuatan pupuk produktif, mendesain alat pembuatan pupuk cair produktif diharapkan akan meningkatkan kualitas dan kuantitas produktivitas beras merah di Tapanuli 
Selatan. Sedangkan Pendidikan konservasi adalah upaya yang sangat vital untuk meningkatkan kesadaran generasi muda, petani, dan masyarakat akan pentingnya menjaga sumber ketahanan pangan lokal dan nasional.

Sinergi, fungsi dan peran antara akademisi, petani, komunitas, pihak terkait dan masyarakat secara aktif dan interaktif dalam pembelajaran, berbagi pengalaman dan motivasi akan menumbuhkembangkan dan meningkatkan kesadaran, peran aktif dan kemandirian masyarakat dalam bentuk ekonomi kreatif dalam meningkatkan taraf kehidupannya. Pentingnya berbagi pengalaman dan introduksi sains dan iptek kepada masyarakat/mitra tani dalam pemanfataan bidang pertanian dalam mendukung sumber minuman bagi masyarakat kita. Disamping itu, perlu dilakukan motivasi dan pelatihan edukasi dengan meningkatkan mutu produk kopi yang diolah menjadi sumber minuman trendi serta terjamin (Gambar 2).

Sedangkan solusi yang berkaitan dengan produktivitas kopi telah dilakukan sejak tahun 2005 hingga tahun 2027. Penelitian dan pengabdian yang telah dilakukan fokus, diantaranya adalah budidaya dan pengelolaan hama dan penyakit kopi di Kabupaten Deli Serdang, Kab. Serdang Bedagai dan Kab. Langkat pada tahun 2005-2010. Selanjutnya pada tahun 2010-2015 mengidentifikasi dan sosialisasi penggunaan atrakatan kopi ramah lingkungan. Kemudian pada tahun 2016-sekarang mengidentifikasi hamahama kopi, penanggulana dan teknologi inovasi pada kopi arabika di Simalungun, Tapsel dan Madina. Kelangkaan bibit ungguil kopi arabika spesifik lokal dan berharga murah ditawarkan pemberdayaan masyarakat berupa kegiatan Focus Discussion Group (FDG), pengumpulan plasma nuftah (bank genetik), pembibitan, penanaman kopi arabikasecara simultan, pelatihan pembuatan pupuk, pembuatan pestisida nabati tepat guna. Selain itu program eduwisata dan pendidikan konservasi juga ditawarkan kepada pelajar sebagai generasi muda dan masyarakat untuk membantu mengembangkan produksi kopi di wilayah tempat tinggal mereka.

Untuk itu perlu dilakukan pendampingan dan pelatihan oleh Tim Program Pengabdian Desa Binaan (PPMDB) LPPM USU berkoordinasi dengan FK USU dan FP USU dalam memberi pengetahuan dan keterampilan. Bimbingan teknis pengelolaan limbah kopi dan penggunaan mesin pengolahan pascapanen khususnya dalam kegiatan ini yaitu mesin pulper kopi kepada petani kopi dan penjelasan prinsip kerja mesin terkait pemanenan kopi dan pengolahan pasca panen kopi yang telah ada untuk membuka wawasan para petani kopi. Selain itu, kegiatan tersebut juga bertujuan untuk memotivasi para petani untuk dapat menghasilkan kopi dengan kualitas nomor 1 dalam kuantitas yang besar, serta dapat mengolah kopi yang dihasilkan tersebut menjadi produk kopi beras, kopi sangrai dan kopi bubuk dengan kualitas mutu yang tinggi. 


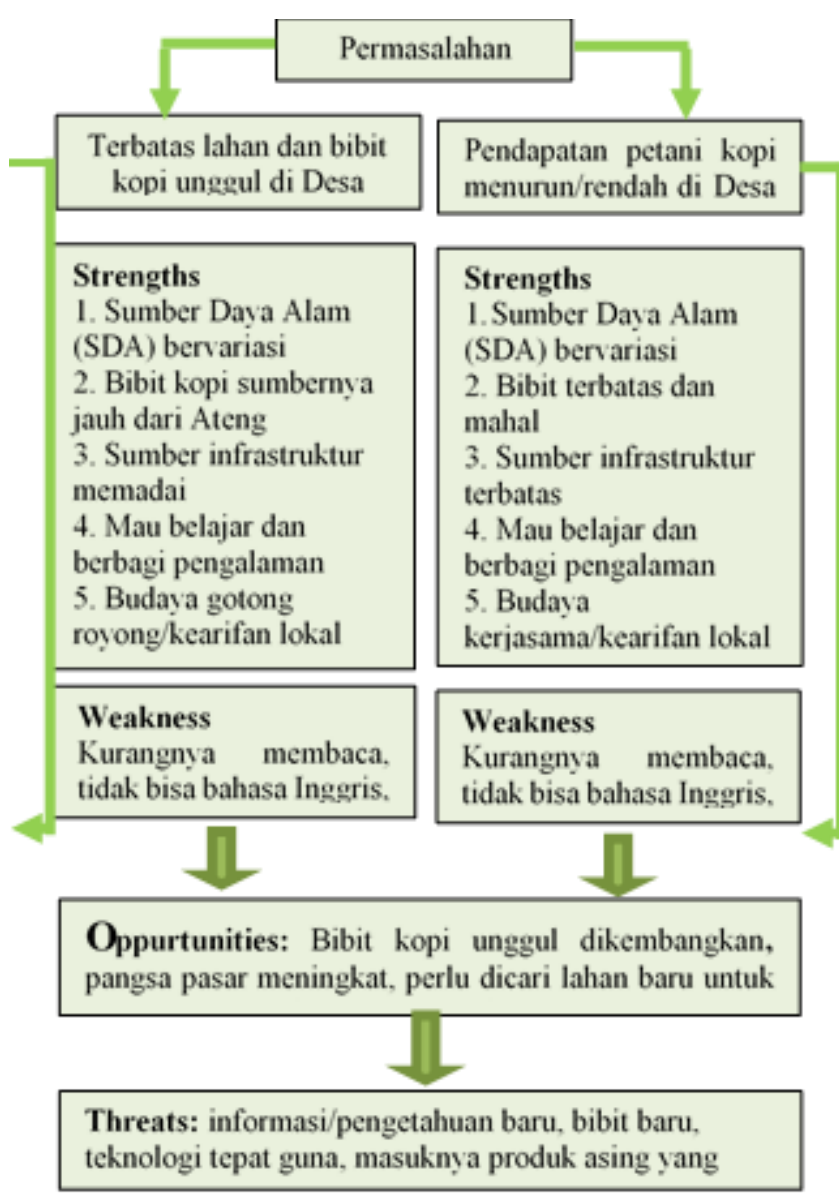

Gambar 2. Skema solusi Analisa SWOT

\subsection{Pelaksanaan Program Pengabdian Masyarakat Desa Binaan (PDB)}

Kegiatan pengabdian masyarakat ini dilakukan oleh Tim Pengabdian Masyarakat Desa Binaan Lembaga Pengabdian Kepada Masyarakat (LPPM) Universitas Sumatera Utara dengan Fakultas Kedokteran USU terhadap masyarakat petani kopi di Desa Telagah, Kecamatan Sei Bingei, Kabupaten Langkat, Sumatera Utara telah dilaksanakan bulan Juli 2021 sampai September 2021. Selanjutnya bulan Oktober-Nopember 2021 akan dilakukan Monev LPPM USU, penyusunan dan penyerahan laporan ke LPPM USU.

Program Pengabdian Masyarakat (PPM) Desa Binaan dilaksanakan di Desa Telagah, Kec. Sei Bingei, Kab. Langkat yang berjarak sekitar $60 \mathrm{~km}$ dari kampus USU Medan, ditempuh dengan mobil sekitar 2 jam perjalanan (Gambar 1). Terdapat beberapa lokasi wisata, seperti: Bekancan River, Lau Kulap, Telagah, Kolam Abadi, Air Terjun Pelaruga, Air Terjun Dua Warna, Pelaruga. Teroh-Teroh, Rumah Pohon Habitat, Sabah Simelir, Air Terjun Namo Belanga, Air Terjun Saringgana, dan lainnya. Di Desa Telagah teridentifikasi pertanaman asam gelugor, kecombrang, kopi, aren, padi dan tanaman hortikultura lainnya di kelilingi Taman Nasional Gunung Leuser (TNGL)

Di Desa Telagah diidentifikasi sumber pencaharian bidang pertanian, diantaranya adalah padi, tanaman sayuran, buah-buahan, kopi, kecombrang, asam gelugor, bamboo, aren, dan lainnya. Sebelum tahun 2000-an, semua 
kopi arabika yang berasal dari Sumatera dikenal dengan kopi Mandaheling, kopi Gayo, kopi Ateng berasal dari Aceh Tengah, kopi Sigargarutang, kopi Sipirok, kopi Tarutung, dan kopi Sidikalang. Diprediksikan tanaman kopi cocok tumbuh pada ketinggian tempat di atas 500-700 m di atas permukaan laut (dpl), curah hujan sebesar $1500-2500 \mathrm{~mm}$ per tahun, dengan rata-rata bulan kering 1-3 bulan dan suhu rata-rata $15^{\circ}-25^{\circ} \mathrm{C}$ dengan lahan kelas S1 atau S2 (Puslitkoka, 2006). Kondisi lingkungan ini ditemukan di Desa Telagah, Langkat sebagai lokasi yang sesuai untuk pertanaman kopi.

Ketua Lembaga Penelitian Pengabdian Masyarakat USU, yang diketuai oleh Prof. Tulus, Vor. Dipl. Math, M.Si, Ph.D melalui Pengabdian Masyarakat (Pemas) Fakultas Kedokteran USU, sejak bulan Juli sampai Oktober 2021. Manakala sub bidang Pertanian melakukan penyerahan dana pembangunan 3 set para-para untuk penjemuran kopi (Gambar 1), pelatihan pembuatan pakan ternak dari kulit kopi secara virtual webinar (Gambar 2 dan Gambar 3), serta penyerahan 1 set alat huller kopi (Gambar 4) kepada Poktan Kopi yang dikoordinir oleh Kepala Desa Bapak Suranta Sitepu. Beliau berharap program Pengabdian Desa Binaan Binaan (PPDB) dengan pendampingan petani kopi Telagah akan menjadikan Desa Telagah sebagai model keseragaman dan kuantitas kopi.Muaranya diharapkan dapat membantu meningkatkan produktivitas dan profit petani kopi di Desa Telagah.

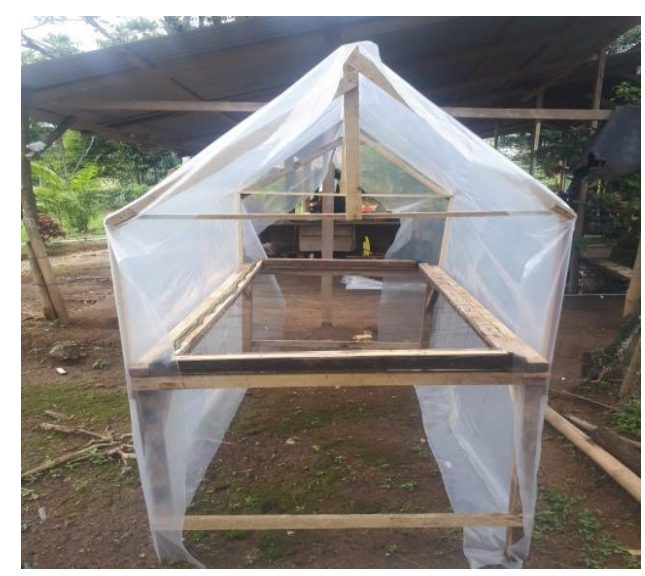

Gambar 3. Para-para penjemur kopi
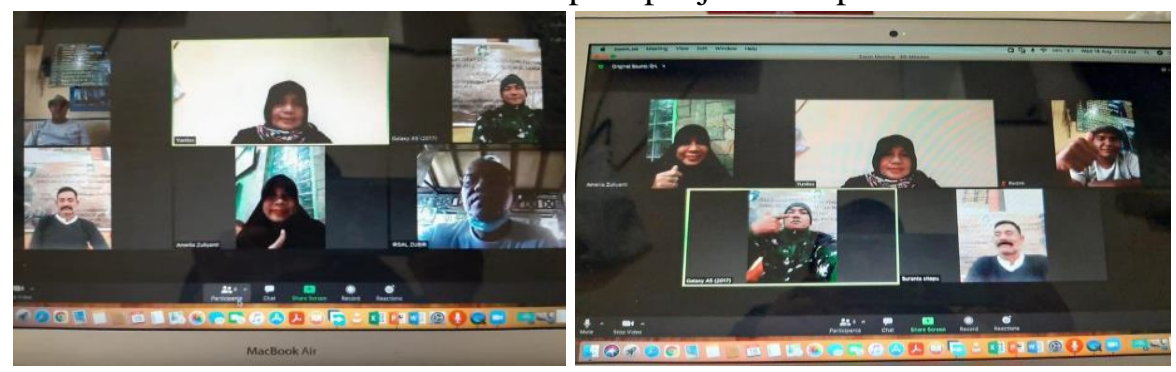

Gambar 4. Pelatihan virtual pemanfaatan limbah kulit kopi menjadi pakan ternak 


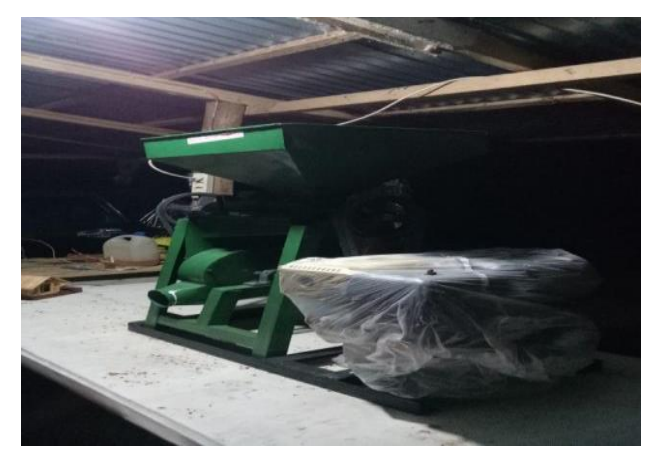

Gambar 4.Alat huller kopi

Permasalahan yang diidentifikasi pada Mitra, meliputi potensi luas lahan di Desa Telagah dapat dikembangkan untuk luas areal tanaman agroforestri tanaman kopi; identifikasi tipe tanah dan kesesuaian lahan dalam pertanaman kopi Ateng; Pengendalian Hama dan Penyakit Terpadu Kopi Ateng serta belum diketahui pengelolaan kulit kopi menjadi pakan ternak tepat guna.

Selanjutnya, Ameilia Zuliyanti Siregar, M.Sc, Ph.D sebagai koordinator Pemas bidang Pertanian menyampaikan Pengabdian dilakukan dalam rangka mendukung ekonomi kreatif petani kopi di Kabupaten Langkat degan konsep ekosistem berwawasan lingkungan berkelanjutan. Kegiatan meliputi pelatihan, bimbingan teknis, dan pendampingan yang akan diintroduksi kepada mitra dalam bentuk induksi dan adopsi pengetahuan tentang pengendalian hama terpadu kopi secara biologi dan kimiawi, pengelolaan limbah kopi dan mekanisme pengupasan kulit kopi mekanik. Tujuannya dalam upaya peningkatan produksi kopi petani dengan menganalisis permasalahan dan strategi pengembangan dan konservasi kopi, minuman penikmat rasa yang sudah menjadi tren masa kini. Pada Tahun 2020, telah disumbangkan 500 bibit kopi Ateng dan pelatihan budidaya serta pengendalian hama dan penyakit terpadu (PHT) kepada Koptan Kopi Telagah.

Manakala anggota Tim Pengabdian Masyarakat USU, Ir Irsal, M.P menyampaikan pada Tahun 2021 ini difokuskan membuat para-para (tempat penjemur kopi) dan menyumbangkan 1 set huller kopi serta konsisi PPKM membuat kami harus melakukan pelatihan secara virtual prmbuatan pupuk dan pakan dari limbah kopi yang disampaikan ibu Dr.Ir.Yunilas, MP serta pengendalian hama dan penyakit tanaman kopi oleh ibu Ameilia Zuliyanti Siregar, M.Sc,Ph.D.

Metode pendekatan yang dilakukan selama pelaksanaan program pengabdian adalah melalui survei potensi/permasalahan di Desa Telagah, Kecamatan Sei Bingei, Kabupaten Langkat, Sumatera Utara. Kemudian dilanjutkan program Focus Discussion Group (FDG), Pelatihan, Aksi/Kegiatan dan Pendampingan secara daring virtual dan offline fokus kepada perwakilan 4 orang petani kopi, Bapak Suranta Sitepu, Bapak Darius, Herman Ginting dan Irman. Jika sudah tidak PPKM, Tim Pengabdian Desa Binaan LPPM USU akan melakukan pendampingan dan diskusi dengan petani kopi dan masyarakat di Desa Telagah. Kegiatan dilanjutkan dengan pelatihan dan praktek di lapangan. Tim Pengabdian Masyarakat Desa Binaan 
LPPM USU akan terus membimbing dan mendampingi hingga luaran yang diharapkan akan tercapai.

Motivasi yang kuat dari pihak mitra petani kopi di Desa Telagah untuk menghasilkan panen kopi unggul berkualitas merupakan salah satu modal yang kuat untuk melaksanakan kegiatan pengabdian pada masyarakat di daerah tersebut. Oleh karena itu perlu disinergikan antara sivitas akademik dengan masyarakat dalam menyelesaikan masalah ini. Untuk mendukung strategi pemecahan masalah mitra petani kopi, dilakukan tahapan sebagai berikut: Kegiatan pengabdian PKM berjudul "Model Edukop Mengelola Kopi Arabica Mendukung Wisata Telagah" dimulai Bulan April 2021 hingga November 2021. Motivasi yang kuat dari pihak mitra untuk menghasilkan panen kopi arabika unggul lokal merupakan salah satu modal yang kuat untuk melaksanakan kegiatan PKMDB di daerah tersebut. Oleh karena itu perlu disinergikan bersama antara sivitas akademik dengan masyarakat dalam menyelesaikan masalah ini dengan cara menentukan strategi pemecahan masalah mitra melalui ipteks akan dilakukan tahapan-tahapan sebagai berikut:

\section{Tahap Persiapan}

Pada tahap persiapan dilakukan survei lokasi, inventarisasi permasalahan mitra, analisis masalah dan mencari solusi dengan pendekatan sain dan teknologi. Kemudian permasalahan tersebut dituangkan kedalam bentuk proposal pengabdian masyarakat yang diajukan kepada LPPM USU dalam skim Non PNBP-PDB LPPM USU.

\section{Tahap Pelaksanaan}

Pada tahap pelaksanaan, tim PDM akan melakukan pembuatan pembuatan pakan ternak dari limbah kopi, desain dan penggunaan alat pengupas biji kopi (pulp pulper). Alat tersebut akan diuji terlebih dahulu sebelum di mobilisasi ke lokasi pengabdian pada masyarakat. Setelah lolos dalam melakukan serangkaian uji yang dilakukan, maka alat pengolahan akan dimobilisasi ke lokasi pengabdian.

3. Tahap Pembimbingan

Pada tahap pembimbingan, akan dilakukan langsung oleh tim PKM dibantu oleh beberapa orang mahasiswa yang dilaksanakan di lokasi PDB LPPM USU.

4.Pengendalian hama terpadu kopi

Kegiatan Sosialisasi, Fokus Grup Diskusi (FGD) dan Pelatihan serta demonstrasi pembuatan pakan ternak dari limbah kopi serta penggunaan alat pulp pulper akan disampaikan kepada mitra "PKMDB Kopi Telagah".

\section{Penanganan Pascapanen Kopi}

Kelompok Petani PKM Kopi Telagah akan diberikan informasi mengenai pengolahan kopi tepat guna, pelatihan pemanfaatan limbah kulit kopi untuk pakan ternak serta Bimbingan Teknis penggunaan alat pengupas biji kopi (pulp pulper). Adapun pelaksanaan kegiatan PKM selama setahun yang akan dilakukan kepada mitra digambarkan dalam diagram alir Gambar 3 dibawah ini. 


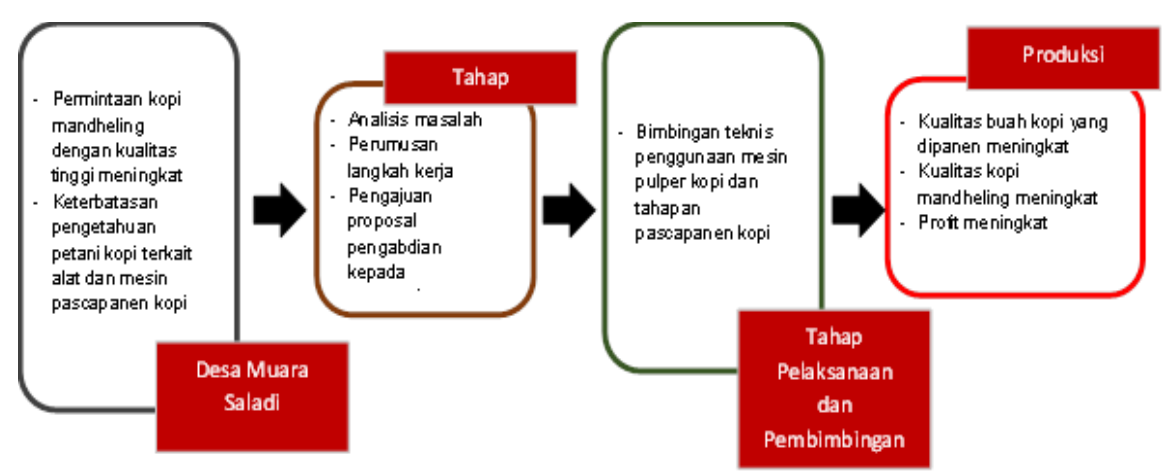

Gambar 5. Diagram Strategi Pemecahan Masalah Mitra

Pembimbingan teknis penggunaan mesin pulper dengan dimensi keseluruhan 670 x 400 x 1310 mm dalam kegiatan pascapanen kopi. Spesifikasi mesin huller kopi yang digunakan ditunjukkan pada Tabel 2.

Pembimbingan teknis penggunaan mesin pulper dengan dimensi keseluruhan 670 x 400 x $1310 \mathrm{~mm}$ dalam kegiatan pascapanen kopi. Spesifikasi mesin huller kopi yang digunakan ditunjukkan pada Tabel 2.

Tabel 2. Spesifikasi mesin huller kopi

\begin{tabular}{lll}
\hline No. & Keterangan & Dimensi \\
\hline 1 & Motor penggerak & $5.5 \mathrm{HP}$ \\
2 & Hopper & $400 \times 310 \times 225 \mathrm{~mm}$ \\
3 & Diameter silinder pengupas & $200 \mathrm{~mm}$, Panjang $275 \mathrm{~mm}$ \\
4 & Corong Pengeluaran & $240 \times 105 \mathrm{~mm}$ \\
5 & Kapasitas input & $264 \mathrm{~kg} / \mathrm{jam}$ \\
6 & Kapasitas keluaran & $174 \mathrm{~kg} / \mathrm{jam}$ \\
\hline
\end{tabular}

Mitra berpartisipasi aktif dan mendukung dalam pelaksanaan program agar berjalan dengan baik. Partisipasi yang diberikan mitra berupa penyediaan lahan, penyediaan bibit ikan dan benih padi merah, bersedia menyumbangkan tenaga, pikiran dan kontribusi waktu. Disamping itu, mitra bersedia berkoordinasi dengan tim PDB, pihak terkait dalam mendukung keberhasilan Program PKM Kopi Telagah. Monitoring dan Evaluasi program dilakukan secara berkala, baik secara tidak langsung menggunakan media virtual online (Google Meet, Whatsapp, telepon, sms) dan langsung saat visitasi kelokasi pertanaman kopi di Desa Telagah, Sei Bingei.

\section{Kesimpulan}

Dari hasil PPM Desa Binaan di Desa Telagah pada Tahun 2021 dapat disimpulkan:

1. Teridentifikasi permasalahan yang mempengaruhi kuantitas dan kualitas tanaman kopi, terdiri dari: kurangnya pengetahuan mitra (Poktan Kopi di Desa Telagah) dalam penanggulangan hama dan penyakit tanaman menggunakan bahan kimiawi (pestisida, herbisida, insektisida) serta pengelolaan limbah kulit kopi sebagai pakan ternak dan pupuk.

2. Peningkatan pengetahuan mitra tani dalam pengendalian hama dan penyakit tanaman secara fisik (menggunakan perangkap warna, cahaya lampu, perangkap aroma) dan secara biologis (pemanfaatan predator capung) dalam menanggulangi hama tanaman kopi Ateng Arabika. 
3. Memberikan informasi pengelolaan limbah kulit kopi secara teratur dan berkesinambungan.

4. Mensosialisasikan kePoktan kopi di Desa Telagah menggunakan parapara untuk menjemur kopi agar kualitasnya bagus.

\section{DAFTAR PUSTAKA}

Ayelign, A., K. Sabally. 2013. Determination of Chlorogenic Acids (CGA) in Coffee Beans Using HPLC. American Journal of Research Communication 1 (2): 78-91.

Badan Pusat Statistik Kabupaten Mandailing Natal. 2017. Kecamatan Ulu Pungkut dalam Dalam Angka 2017 - https://mandailingnatalkab.bps.go.id.

Ernawanto,Q.D dan T.Sudaryono, 2016. Rehabilitasi Lahan Marginal dalam Rangka Meningkatkan Produktivitas dan Konservasi Air. Prosiding Seminar Nasional Inovasi Teknologi Pertanian, Banjabaru, 20 Juli 2016.

Hulupi,R. dan Endri M, 2013. Budidaya dan Pemeliharaan Tanaman Kopi di Kebun Campur. Pusat Penelitian dan Kopi dan Kakao Indonesia bekerjasama dengan World Agrofoestry Centre. www.worldsgroforestri.org.

Hoffman, James. 2014. The World Atlas of Coffee: From Beans to Brewing - Coffees Explored, Explained and Enjoyed. Octopus Publishing Group Limited. London.

International Coffee Organization (ICO). 2015. ICO Annual Review 2013-2014. International Coffee Organization. London

Lahuddin, Hardy, G., Bintang, S. dan Risna, A.Y. 2010. Interaksi Kompos dan Dolomit : Efek Interaksi Perlakuan Kompos dan Dolomit pada Tanah Sangat Asam Terhadap Berat Kering Tanaman, Keasaman Tanah, Kandungan C dan N Total dalam Tanah. Jurnal IImu Pertanian Kultivar. 4 (1). Fakultas Pertanian, Universitas Sumatera Utara, Medan.

Lukman. 2013. Singapura Lirik Kopi Ulu Pungkut. Diunduh dari http://www.mandailingonline.com/singapura-lirik-bubuk-kopi-ulupungkut, diakses November 2018.

Mekuria, T., Neuhoff, D., Kopke, U. 2004. The Status of Coffee Production and The Potential For Organic Conversion in Ethiopia. Conference on International Agricultural Research for Development. Berlin.

Nawrot, P., S. Jordan., J. Eastwood., J. Rotstein., A. Hugenholtz., M. Feeley. 2003. Effects of Caffeine on Human Health. Food Additives and Contaminants 20(1): 1-30.

Pane, M.A., Madjid, M.B.D. dan Bintang, S. 2014. Pemberian Bahan Organik Kompos Jerami Padi dan Abu Sekam Padi dalam Memperbaiki Sifat Kimia Tanah Ultisol Serta Pertumbuhan Tanaman Jagung. Jurnal Online Agroekoteknologi. 2 (4). Universitas Sumatera Utara, Medan.

Peraturan Menteri Dalam Negeri Nomor 137 Tahun 2017 tentang Kode dan Data Wilayah Administrasi Pemerintahan". Kementerian Dalam Negeri Republik Indonesia. Diakses tanggal 18 Maret 2020. 
Smith, A. 2002. Effects of Caffeine on Human Behavior. Food and Chemical Toxicology 40: 1243-1255.

Panggabean, Edy. 2011. Buku Pintar Kopi. PT. AgroMedia Pustaka. Jakarta.

Ponte, Stefano. 2002. The 'Latte Revolution'? Rekopition, Markets and Consumption in the Global Coffee Chain. World Developmen (7): 1099-1122.

Toguria, N.R., Diana C., Sinar I.K. 2018. Strategi Pengembangan Agribisnis Kopi Mandailing (Coffea arabica). Studi Kasus: Desa Simpang Banyak Julu, Kecamatan Ulu Pungkut, Kabupaten Mandailing Natal 